\title{
Studies in rats on the nutritional value of hydrogen peroxide-treated fish protein and the utilization of oxidized sulphur-amino acids
}

\author{
BY L. B. SJÖBERG AND S. L. BOSTRÖM* \\ Astra Nutrition AB, Fack, S-431 20 Mölndal, Sweden
}

(Received 9 July 1976 - Accepted 26 July 1976)

1. The nutritional value of fish protein oxidized with different levels of hydrogen peroxide, and the utilization of oxidized sulphur-amino acids in the rat were investigated.

2. The results showed that the biological value (BV) and protein efficiency ratio (PER) of the fish protein were significantly decreased by the treatment with $\mathrm{H}_{2} \mathrm{O}_{2}$, and although there were no significant differences between samples treated with 20,40 or $80 \mathrm{~g} \mathrm{H}_{2} \mathrm{O}_{2} / \mathrm{kg}$, there was a gradual decrease of $\mathrm{BV}$ at higher concentrations. Digestibility was not affected by the treatment.

3. Supplementation with $1 \mathrm{~g} \mathrm{~L}$-methionine $/ \mathrm{kg}$ or $1 \mathrm{~g} \mathrm{~L}$-cystine $/ \mathrm{kg}$ significantly increased the $\mathrm{BV}$ for all $\mathrm{H}_{2} \mathrm{O}_{2}$-treated samples. With the exception of the sample treated with $80 \mathrm{~g} \mathrm{H}_{2} \mathrm{O}_{2} / \mathrm{kg}$, the $\mathrm{BV}$ was increased by L-methionine supplementation to the level for the untreated fish protein.

4. Treatment with $\mathrm{H}_{2} \mathrm{O}_{2}$ led to the formation of methionine sulphoxide, methionine sulphone and cysteic acid. The availability of these compounds was studied as supplements to the untreated fish protein as well as to the $\mathrm{H}_{2} \mathrm{O}_{2}$-treated fish protein. The results showed that $\mathrm{L}$-methionine DL-sulphoxide was as available as methionine, but that $L$-methionine sulphone and cysteic acid had no supplementary effect.

5. The availability of lysine in fish protein was not affected by treatment with $20 \mathrm{~g} \mathrm{H}_{2} \mathrm{O}_{2} / \mathrm{kg}$ as judged by its effect as a supplement to wheat flour.

6. The plasma amino acid pattern for rats given a diet with $\mathrm{H}_{2} \mathrm{O}_{2}$-treated fish protein was identical to that for rats given an untreated fish protein, with the exception of the presence of the two isomers of $\mathrm{L}$-methionine DL-sulphoxide and L-methionine sulphone. The oxidized S-amino acids were also found in liver, kidney and gastrocnemius muscle from the rat.

7. Only traces of L-methionine DL-sulphoxide were found in the urine. About half the ingested L-methionine sulphone was found in the urine and almost all was present as an acid-labile conjugate.

Treatment of proteins with oxidizing agents like hydrogen peroxide is reported to decrease the nutritional value of the protein (Ellinger \& Palmer (1969), Rasekh, Stillings \& Sidwell (1972), Slump \& Schreuder (1973), Anderson, Li, Jones \& Bender (1975)).

Several explanations have been offered for the decrease in nutritional value. Ellinger \& Palmer (1969) interpreted their results as a reduced availability of methionine in oxidized casein to both growing rats and to the bacteria Streptococcus zymogenes. Rasekh et al. (1972) studied $\mathrm{H}_{2} \mathrm{O}_{2}$-treated fish-protein concentrate and speculated that the observed decrease in protein efficiency ratio (PER) values on oxidation was due to breakdown of cystine or oxidation of methionine to methionine sulphoxide. Slump \& Schreuder (1973) studied $\mathrm{H}_{2} \mathrm{O}_{2}$-treated casein and fish meal, and analysed the oxidized protein samples for methionine, methionine sulphoxide, methionine sulphone, cystine and cysteic acid. They suggested that methionine sulphoxide was completely available to rats and that the decrease in biological value (BV) was due to formation of cysteic acid and methionine sulphone, both unavailable to rats. Anderson et al. (1975) studied $\mathrm{H}_{2} \mathrm{O}_{2}$ treatment of rapeseed flour and concluded that formation of oxidized sulphur-amino acids, in particular methionine sulphone, reduced considerably the nutritional value.

Cuq, Provansal, Guilleux \& Cheftel (1973) found a decreased release of methionine, or its oxidation products, from $\mathrm{H}_{2} \mathrm{O}_{2}$-treated casein on in vitro digestion with Pronase, and concluded that Pronase was unable to split methionyl-peptide bonds when methionine was oxidized to methionine sulphoxide.

\footnotetext{
* Present address: Haessle AB, Fack, S-431 20 Mölndal 1, Sweden.
} 
The availability of free methionine sulphoxide to rats has been studied in several laboratories. Njaa (1962) found that L-methionine sulphoxide was as effective as methionine when used as a supplement to a soya-bean-meal diet. D-methionine sulphoxide was only about $50 \%$ as active as methionine. Miller \& Samuel (1968) found that methionine sulphoxide (isomer not specified) could partly replace methionine as a supplement to a casein diet. Miller, Tannenbaum \& Seitz (1970) approached the problem with diets composed of synthetic amino acids. They found in rats an age-dependent adaptation to a more efficient utilization of methionine sulphoxide. By injecting labelled methionine sulphoxide and methionine sulphone into rats, Smith (1972) showed that approximately $10 \%$ of the methionine sulphoxide and about $50 \%$ of the methionine sulphone was excreted in $24 \mathrm{~h}$. Both methionine sulphoxide and methionine sulphone were mainly excreted as $\mathrm{N}$-acetyl derivatives.

The present study was undertaken to evaluate further the nutritive value of $\mathrm{H}_{2} \mathrm{O}_{2}$-treated fish protein and the availability and general turnover of peptide-bound oxidized S-amino acids. Also findings from studies on dietary supplementation with these amino acids are presented.

\section{MATERIALS AND METHODS}

Samples of fish protein were prepared from frozen blocks of cod filleting offal. Since maximum water-binding capacity and oil-emulsifying properties were aimed at, all processing steps were carried out at a maximum temperature of $50^{\circ}$.

Reference fish-protein sample. This was prepared as follows. The filleting offal was partially deboned and the resulting fish paste was extracted three times with azeotropic propan-2-ol at $50^{\circ}$, the solvent was removed and the sample was deodorized with air saturated with water, and then dried and ground. The composition by analysis was $(\mathrm{g} / \mathrm{kg})$ : protein (nitrogen $\times 6 \cdot 25) 868$, fat 3 , ash 120 .

$\mathrm{H}_{2} \mathrm{O}_{2}$-treated fish-protein samples were produced from the same raw material as the reference sample. Fish paste was mixed with azeotropic propan-2-ol $(1: 1, \mathrm{w} / \mathrm{v})$ and the temperature was increased to $50^{\circ}$. Sodium hydroxide was added to increase the pH to $8 \cdot 5$. $\mathrm{H}_{2} \mathrm{O}_{2}$ solution $(350 \mathrm{ml} / \mathrm{l})$ was then added at $20-80 \mathrm{~g} / \mathrm{kg}$ dry weight of fish substance. The mixture was stirred continuously for $120 \mathrm{~min}$, then additional propan-2-ol was added, and the mixture was centrifuged. The solid phase was further extracted three times with propan-2-ol, the solvent was removed and the sample was deodorized with air saturated with water, and then dried and ground. The composition by analysis was $(\mathrm{g} / \mathrm{kg}): 20 \mathrm{~g} \mathrm{H}_{2} \mathrm{O}_{2} / \mathrm{kg}$ : protein 851 , fat $1 \cdot 5$, ash $133 ; 40 \mathrm{~g} \mathrm{H}_{2} \mathrm{O}_{2} / \mathrm{kg}$ : protein 851 , fat $1 \cdot 4$, ash $130 ; 80 \mathrm{~g} \mathrm{H}_{2} \mathrm{O}_{2} / \mathrm{kg}$ : protein 856 , fat $2 \cdot 3$, ash 129 . The absence of free $\mathrm{H}_{2} \mathrm{O}_{2}$ in the fish-protein samples was confirmed by analysis of $\mathrm{H}_{2} \mathrm{O}_{2}$ with a modification of the thiocyanate method of Hills \& Thiel (1945).

L-methionine DL-sulphoxide and L-methionine sulphone were purchased from Sigma Chemical Co., St Louis, Missouri, USA. L-methionine and L-cystine were purchased from British Drug Houses, Poole, Dorset, UK, and L-cysteic acid from Fluka AG, Buchs, Switzerland. All other chemicals were of analytical grade.

\section{Analytical methods}

$N$ content. The $\mathrm{N}$ contents of fish-protein products and of samples of urine and faeces from animal experiments was determined by the Kjeldahl method, using an automatic apparatus (Kjell Foss; A/SN Foss Electric, Denmark).

Ash content. This was determined in fish-protein products by the method of the Association of Official Analytical Chemists (1970).

Lipid content. This was determined in fish-protein products by extraction with chloroform-methanol $(2: 1, \mathrm{v} / \mathrm{v})$. 
Amino acid composition. This was determined in fish-protein products by hydrolysis in $6 \mathrm{M}$-hydrochloric acid under vacuum at $110^{\circ}$ for $22 \mathrm{~h}$, followed by ion-exchange chromatography essentially according to the method of Stein \& Moore (1954).

$S$-amino acids. Cysteine-cystine was determined as cysteic acid and 'total methionine' as methionine sulphone after oxidation with performic acid according to Moore (1963).

Tryptophan. This was determined according to the method of Spies \& Chambers $(1948,1949)$.

Methionine sulphone and cysteic acid. These were determined after acid-hydrolysis and ion-exchange chromatography (as described previously) as follows.

Methionine sulphoxide was determined by two methods: (a) 'indirect' method, essentially according to Slump \& Schreuder (1973), by alkylation with iodo-acetic acid followed by performic acid oxidation and acid-hydrolysis. Some minor modifications were introduced. To facilitate alkylation with iodo-acetic acid all samples were digested with Alcalase (Novo, Copenhagen) before the alkylation step. The protein sample $(25 \mathrm{mg})$ was suspended in $4 \mathrm{ml} 0.01 \mathrm{M}$-sodium bicarbonate, $\mathrm{pH} 8.5$. Alcalase $(0.25 \mathrm{mg})$ was added and the sample was shaken at $50^{\circ}$ for $6 \mathrm{~h}$. This stage was followed by alkylation with iodo-acetic acid for $40 \mathrm{~h}$ at $40^{\circ}$ in darkness after adjustment of the $\mathrm{pH}$ to 2.0 with $\mathrm{HCl}$. To remove the excess iodo-acetic acid before oxidation with performic acid, the sample was extracted with diethyl ether according to the original procedure of Neumann (1967). The samples were subsequently evaporated nearly to dryness by rotary evaporation at $40^{\circ}$, oxidized with performic acid according to Moore (1963) and hydrolysed with $6 \mathrm{M}-\mathrm{HCl}$ for $18 \mathrm{~h}$. The amount of methionine sulphoxide present in protein samples was calculated as described by Slump \& Schreuder (1973); (b) 'direct' method, in which the content of methionine sulphoxide in test protein samples and in rat faeces was also determined, after alkaline-hydrolysis, essentially according to Neumann (1967). To $10-15 \mathrm{mg}$ sample was added $1 \mathrm{ml} 2 \mathrm{M}$-sodium hydroxide and the mixture was hydrolysed at $100^{\circ}$ for $18 \mathrm{~h}$. Then $6 \mathrm{M}-\mathrm{HCl}$ was added to adjust the $\mathrm{pH}$ to approximately $2 \cdot 0$ followed by dilution with $10 \mathrm{ml}$ of the starting buffer $(\mathrm{pH} 2 \cdot 2)$ for ion-exchange chromatography (see p. 192).

\section{BIOLOGICAL EVALUATIONS}

\section{Animal experiments}

Biological evalutions were performed on rats in $\mathrm{N}$-balance experiments and in growth experiments.

For all animal experiments male rats of the Sprague-Dawley strain (Anticimex, Stockholm) were used. The animals were housed in individual cages in a room with constant relative humidity and temperature $\left(50 \%\right.$ and $21^{\circ}$ respectively) and with a $12 \mathrm{~h}$ light-anddark cycle. Food and water were offered ad lib.

\section{Diet composition}

The diet contained $(\mathrm{g} / \mathrm{kg}$ ): protein 100, fat (groundnut oil) 100 (corrected for fat contribution from test protein sample), cellulose 30 , mineral mixture 50 (corrected for the contribution of ash from test protein sample), vitamin mixture 20 , sucrose to $1 \mathrm{~kg}$. The composition of the mineral mixture (USP salt mixture XIV (US Pharmacopoeia, XIV, 1950) supplemented with trace minerals) was $(\mathrm{g} / \mathrm{kg})$ : calcium carbonate $68 \cdot 3$, calcium citrate $308 \cdot 3$, calcium diphosphate $112 \cdot 8$, magnesium carbonate $35 \cdot 2$, magnesium sulphate $38 \cdot 3$, potassium chloride $124 \cdot 7$, potassium dihydrogen phosphate $218 \cdot 8$, sodium chloride $77 \cdot 1$, ferric ammonium citrate $15 \cdot 281$, cupric sulphate 0.077 , manganese sulphate $4 \cdot 200$, ammonium aluminium sulphate 0.092 , zinc sulphate 0.500 , potassium iodide 0.740 , sodium fluoride 0.507 , cobalt chloride 0.023 , sodium arsenite 0.009 , sodium borate 0.022 , sodium molybdate 0.003 . The vitamin mixture, prepared in glucose, supplied the following when used at $20 \mathrm{~g} / \mathrm{kg}$ diet 
(g/kg diet): retinol $5.94 \mathrm{mg}$, cholecalciferol $0.05 \mathrm{mg}$, ascorbic acid $0.991, \alpha$-tocopherol $0 \cdot 110$, myo-inositol $0 \cdot 110$, choline chloride 1.651 , menaphthone $0.049, p$-aminobenzoic acid $0 \cdot 110$, nicotinic acid 0.099 , riboflavin 0.022 , pyridoxine hydrochloride 0.022 , thiamine hydrochloride 0.022 , calcium pantothenate 0.066 , biotin $0.440 \mathrm{mg}$, pteroylmonoglutamic acid $1.982 \mathrm{mg}$, hydroxocobalamin $0.029 \mathrm{mg}$.

In supplementation experiments amino acids were added at the expense of sucrose.

\section{$N$-balance procedure}

The starting weight of the animals was $70-75 \mathrm{~g}$. Seven animals were randomly assigned to each test diet. A $4 \mathrm{~d}$ adaptation period on the test diet was followed by a $4 \mathrm{~d}$ experimental period, during which weight gain and food intake were recorded, and urine and faeces were collected separately for $\mathrm{N}$ determination. Digestibility, BV, and net protein utilization (NPU) were calculated after correction for endogenous loss of $\mathrm{N}$ on a protein-free diet.

\section{Growth experiments}

The starting weight of the animals was 56-62 $\mathrm{g}$. Ten rats were randomly assigned to each test diet. During a 4-week period food intake and weight gains were recorded. PER was calculated as $\mathrm{g}$ weight gain/g protein eaten.

\section{Blood sampling}

Blood samples for determination of plasma amino acids and plasma urea were taken from the aorta of diethyl ether-anaesthetized animals and collected into heparinized tubes. Blood samples were taken in the morning 1-2 $\mathrm{h}$ after withdrawal of the food. In the later part of the study blood samples for urea determination were taken $6 \mathrm{~h}$ after withdrawal of the food.

Urea. The urea concentration in plasma and urine was determined using a test kit (15930 THAC; Boehringer GmbH, Mannheim, West Germany).

Plasma amino acids. The concentrations were determined by ion-exchange chromatography essentially according to Jeppsson \& Karlsson (1972). Before analysis the blood plasma was deproteinized with solid sulphosalicylic acid, $30 \mathrm{mg} / \mathrm{ml}$ plasma, according to Perry \& Hansen (1969). Deproteinized samples were kept at $-70^{\circ}$ until required for analysis.

Methionine sulphoxide, methionine sulphone and cysteic acid. The concentrations in plasma, urine, kidney, liver and muscle were determined by a modification of the procedure (Jeppsson \& Karlsson, 1972) for ion-exchange chromatography of plasma amino acids. In the Jeppsson \& Karlsson (1972) procedure the elution of the amino acids starts with a lithium buffer, pH 2.80. In this procedure one isomer of methionine sulphoxide is eluted together with methionine sulphone just before threonine and the other isomer is eluted together with threonine. In the first part of this study this procedure was used to obtain a rough estimate of the content of 'oxidized methionine' in plasma and urine. This estimate assumed that the 'peak' of methionine sulphoxide in the threonine 'peak' was the same height as the 'peak' eluted before threonine. During the course of the study a new procedure was developed which gave a better resolution. A $50 \mathrm{~cm}$ column packed with resin (Beckman UR-30 resin; Beckman Instruments Co., Fullerton, California, USA) was used. Elution was started with $0.02 \mathrm{M}$-sodium citrate buffer, $\mathrm{pH} 3.05$. The temperature was $55^{\circ}$. A typical elution pattern for plasma as obtained by this modified procedure is presented in Fig. 2.

Before urine analysis of methionine sulphoxide and methionine sulphone, urine samples were deproteinized with cold acetone $(4: 1, v / v)$. Since acetone precipitation of urine gave low recovery of cysteic acid, precipitation was subsequently done with solid sulphosalicylic acid $(30 \mathrm{mg} / \mathrm{ml})$. Addition of free cysteic acid before treatment showed a $10 \%$ loss on handling and, therefore, values for cysteic acid were corrected for this loss. 
Kidney, liver and muscle were homogenized in cold distilled water $(1: 3, \mathrm{w} / \mathrm{v})$, centrifuged and the supernatant fraction was treated with sulphosalicylic acid for protein precipitation (30 $\mathrm{mg} / \mathrm{ml}$ supernatant fraction).

Thin-layer chromatography. For further identification of methionine sulphoxide and methionine sulphone in plasma, the respective fractions from the ion-exchange chromatography separation werre collected. Dansyl derivatives of the fractions were synthesized and analysed by thin-layer chromatography on silica gel according to the methods of Gray \& Hartley (1963) and Gros \& Labousse (1969).

The presence of acid-labile derivatives of methionine sulphone and cysteic acid (e.g. $\mathrm{N}$-acetyl derivatives; Smith, 1972) was determined in urine, plasma liver, kidney and muscle by subjecting the material to hydrolysis with $2 \mathrm{M}-\mathrm{HCl}$ for $3 \mathrm{~h}$ at $110^{\circ}$. This procedure was shown to deconjugate $\mathrm{N}$-acetyl methionine. Values were compared with results for sample not subjected to acid-hydrolysis.

The acid-hydrolysis technique was originally intended to be used also for determination of derivatives of methionine sulphoxide, since methionine sulphoxide was stable under these conditions in the test systems investigated. However, it was found that methionine sulphoxide was not stable in urine and plasma under these conditions and therefore an alkaline-hydrolysis method had to be used (Ivanetich, Bradstrom \& Kaminsky (1976) reported a yield of more than $85 \%$ for methionine sulphoxide after alkaline-hydrolysis of $\mathrm{N}$-acetylmethionine sulphoxide).

Alkali-labile derivatives of methionine sulphoxide. These derivatives were determined in plasma, kidney, liver, muscle and urine after protein precipitation with sulphosalicylic acid (for plasma and kidney determinations were also made after protein precipitation with acetone) followed by alkaline-hydrolysis $\left(2 \mathrm{M}-\mathrm{NaOH}\right.$ for $18 \mathrm{~h}$ at $\left.110^{\circ}\right)$ and ion-exchange chromatography. Values were compared with results for samples not subjected to alkalinehydrolysis.

\section{Statistical treatment}

Values are presented as mean values with their standard errors. Statistical significance was calculated by the use of Student's $t$ test; $P<0.05$ was regarded as statistically significant.

\section{RESULTS}

\section{Amino acid composition}

Table 1 shows the effect of $\mathrm{H}_{2} \mathrm{O}_{2}$ treatment on the amino acid composition. As can be seen both methionine and cystine were partially oxidized. Most of the methionine sulphoxide, as well as cysteic acid, was already formed by treatment at $20 \mathrm{~g} \mathrm{H}_{2} \mathrm{O}_{2} / \mathrm{kg}$ diet, with only a moderate successive increase at higher concentrations of $\mathrm{H}_{2} \mathrm{O}_{2}$. 'Indirect' or 'direct' methods for determination of methionine sulphoxide gave similar results, but only results from 'indirect' determination are presented. With methionine sulphone there was, however, a more pronounced progressive increase with increasing $\mathrm{H}_{2} \mathrm{O}_{2}$ concentrations. It is interesting to note the presence of methionine sulphoxide as well as cysteic acid in the reference material.

Of the other amino acids present, the contents of tryptophan, histidine and lysine seemed to be reduced by the treatment with $\mathrm{H}_{2} \mathrm{O}_{2}$.

\section{Animal experiments}

Since methionine is the first limiting amino acid in fish protein (Stillings, Hammerle \& Snyder, 1969), conversion of methionine to unavailable derivatives should lead to a decrease in nutritional value. 
Table 1. Amino acid composition of fish protein treated with hydrogen peroxide

\begin{tabular}{|c|c|c|c|c|}
\hline \multirow[b]{2}{*}{$\mathrm{H}_{2} \mathrm{O}_{2}$ added $(\mathrm{g} / \mathrm{kg})$} & \multicolumn{4}{|c|}{ Amino acid content $(\mathrm{g} / \mathrm{kg}$ protein (nitrogen $\times 6.25)$ ) } \\
\hline & 0 (control) & 20 & 40 & 80 \\
\hline Amino acid & & & & \\
\hline Aspartic acid & $10 \cdot 12$ & $9 \cdot 87$ & $10 \cdot 15$ & $10 \cdot 22$ \\
\hline Threonine & $4 \cdot 71$ & $4 \cdot 54$ & $4 \cdot 69$ & $4 \cdot 58$ \\
\hline Serine & $4 \cdot 57$ & $4 \cdot 41$ & $4-45$ & $4 \cdot 47$ \\
\hline Glutamatic acid & 14.86 & $14 \cdot 34$ & $14 \cdot 47$ & $14 \cdot 67$ \\
\hline Proline & 4.91 & $4 \cdot 70$ & 4.50 & $4 \cdot 73$ \\
\hline Glycine & 6.08 & $5 \cdot 81$ & $5 \cdot 89$ & $6 \cdot 14$ \\
\hline Alanine & $6 \cdot 29$ & $6 \cdot 11$ & $6 \cdot 20$ & $6 \cdot 29$ \\
\hline Valine & $5 \cdot 54$ & $5 \cdot 40$ & $5 \cdot 50$ & $5 \cdot 40$ \\
\hline Methionine* & $3 \cdot 50$ & $3 \cdot 54$ & $3 \cdot 20$ & $3 \cdot 43$ \\
\hline Isoleucine & $4 \cdot 57$ & $4 \cdot 43$ & $4 \cdot 53$ & $4 \cdot 51$ \\
\hline Leucine & 8.02 & $7 \cdot 73$ & $7 \cdot 81$ & 7.99 \\
\hline Tyrosine & $3 \cdot 58$ & $3 \cdot 14$ & $3 \cdot 21$ & 3.23 \\
\hline Phenylalanine & $4 \cdot 23$ & $4 \cdot 25$ & $4 \cdot 24$ & $4 \cdot 16$ \\
\hline Lysine & 8.98 & $8 \cdot 64$ & $8 \cdot 07$ & 6.94 \\
\hline Histidine & $2 \cdot 63$ & $2 \cdot 36$ & $2 \cdot 35$ & $2 \cdot 12$ \\
\hline Arginine & $6 \cdot 54$ & $6 \cdot 39$ & 6.25 & $6 \cdot 29$ \\
\hline Cystine* & $1 \cdot 15$ & $1 \cdot 10$ & $1 \cdot 15$ & $1 \cdot 19$ \\
\hline Tryptophan & 1.69 & $1 \cdot 36$ & $1 \cdot 23$ & 0.95 \\
\hline Methionine sulphoxide $\dagger$ & 0.41 & $2 \cdot 12$ & 2.48 & $2 \cdot 20$ \\
\hline Methionine sulphone & 0.00 & 0.17 & 0.31 & 0.57 \\
\hline $\begin{array}{l}\text { Cysteic acid } \\
\text { (calculated as cystine) }\end{array}$ & 0.08 & 0.62 & 0.67 & 0.81 \\
\hline
\end{tabular}

The influence of the treatment with $\mathrm{H}_{2} \mathrm{O}_{2}$ was tested in $\mathrm{N}$-balance and growth experiments. Results from N-balance experiments are shown in Table 2. The results show that the $\mathrm{BV}$ was significantly decreased in the samples treated with $\mathrm{H}_{2} \mathrm{O}_{2}$. There was a significant decrease in $\mathrm{BV}$ with $\mathrm{H}_{2} \mathrm{O}_{2}$ treatment at $20 \mathrm{~g} / \mathrm{kg}$ diet, and there was no significant difference between treatments $\left(20,40\right.$ and $80 \mathrm{~g} \mathrm{H}_{2} \mathrm{O}_{2} / \mathrm{kg}$ diet $)$ although there was a further gradual decrease in the $\mathrm{BV}$ at higher concentrations of $\mathrm{H}_{2} \mathrm{O}_{2}$. Over-all digestibility was not affected by the treatment. Corresponding values for a casein diet are: digestibility $94, \mathrm{BV} 82$, NPU 78 .

As a measure of the nutritional value, values for plasma urea concentration and the amount of urea- $\mathrm{N}$ relative to total $\mathrm{N}$ in urine are included in Table 2. Plasma urea level has been shown by Eggum (1973) to be inversely correlated with the BV of proteins. As can be seen there was an increase in plasma urea- $\mathrm{N}$ as well as in the value for urine urea- $\mathrm{N}$ : total$\mathrm{N}$ in urine on treatment with $\mathrm{H}_{2} \mathrm{O}_{2}$.

Results from growth experiments are presented in Table 3. The results showed a decrease in growth and food efficiency on treatment with $\mathrm{H}_{2} \mathrm{O}_{2}$. Values for a casein diet are included as a reference. The results paralleled those from the $\mathrm{N}$-balance experiments except for the sample treated with $80 \mathrm{~g} \mathrm{H}_{2} \mathrm{O}_{2} / \mathrm{kg}$, which in the growth experiment showed a greater loss of nutritional value.

\section{Supplementation experiments}

Supplementation with $1 \mathrm{~g}$ L-methionine/ $\mathrm{kg}$ diet significantly increased the BV for the $\mathrm{H}_{2} \mathrm{O}_{2}$-treated samples as well as for the reference sample (Table 2). However, the sample treated with $80 \mathrm{~g} \mathrm{H}_{2} / \mathrm{O}_{2} / \mathrm{kg}$ still showed a lower BV than the unsupplemented reference sample and an attempt to further increase the BV by supplementation with $2 \mathrm{~g} \mathrm{~L}$-methionine/ $\mathrm{kg}$ diet was unsuccessful. The BV for the sample treated with $40 \mathrm{~g} \mathrm{H}_{2} \mathrm{O}_{2} / \mathrm{kg}$ was not increased 


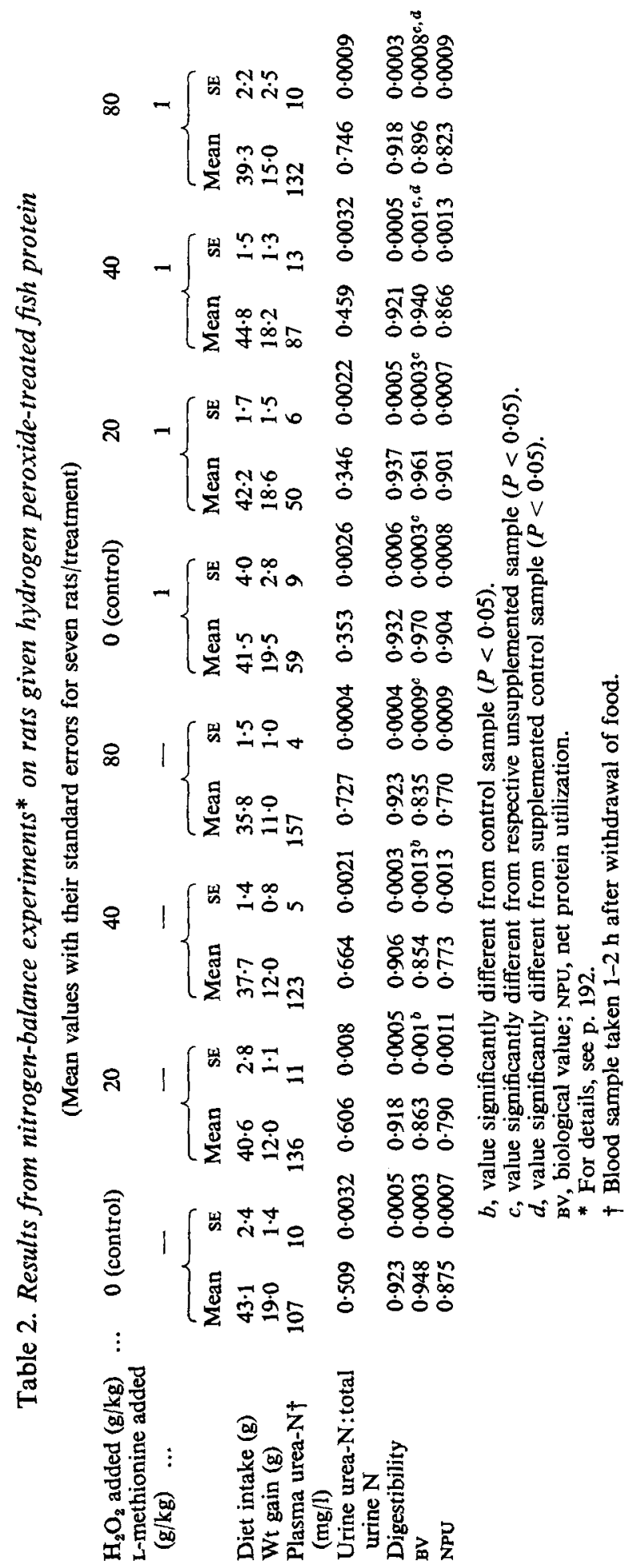




\section{Table 3. Results from growth experiments $\dagger$ on rats given} hydrogen peroxide-treated fish protein

(Mean values with their standard errors for ten rats/treatment)

\begin{tabular}{|c|c|c|c|c|c|c|}
\hline \multirow[b]{2}{*}{ Diet $\ldots$} & \multicolumn{2}{|c|}{ Food intake (g) } & \multicolumn{2}{|c|}{ Wt gain (g) } & \multicolumn{2}{|c|}{ PER } \\
\hline & Mean & SE & Mean & SE & Mean & SE \\
\hline $\begin{array}{l}\text { Control } \\
\text { Control }+20 \mathrm{~g} \mathrm{H}_{2} \mathrm{O}_{2} / \mathrm{kg} \\
\text { Control }+40 \mathrm{~g} \mathrm{H}_{2} \mathrm{O}_{2} / \mathrm{kg} \\
\text { Control }+80 \mathrm{~g} \mathrm{H}_{2} \mathrm{O}_{2} / \mathrm{kg} \\
\text { Casein }\end{array}$ & $\begin{array}{l}295 \cdot 9 \\
270 \cdot 2 \\
265 \cdot 9 \\
210 \cdot 1 \\
288 \cdot 4\end{array}$ & $\begin{array}{r}10 \cdot 8 \\
6 \cdot 7 \\
12 \cdot 6 \\
10 \cdot 2 \\
9 \cdot 6\end{array}$ & $\begin{array}{r}100 \cdot 5 \\
73 \cdot 5 \\
72 \cdot 7 \\
45 \cdot 0 \\
91 \cdot 4\end{array}$ & $\begin{array}{l}4.5 \\
3.0 \\
4 \cdot 3 \\
2.9 \\
3.8\end{array}$ & $\begin{array}{l}3 \cdot 42 \\
2 \cdot 72 \\
2 \cdot 75 \\
2 \cdot 14 \\
3 \cdot 17\end{array}$ & $\begin{array}{l}0.19 \\
0.17^{*} \\
0.13^{*} \\
0.17^{*} \\
0.14\end{array}$ \\
\hline
\end{tabular}

PER, protein efficiency ratio.

* Significantly different from control sample $(P<0.05)$.

† For details, see p. 192.

Table 4. Nitrogen-balance experiments $\dagger$ on rats given reference fish protein supplemented with methionine, methionine sulphoxide, methionine sulphone and cysteine

(Mean values with their standard errors for seven rats/treatment except the control diet where fourteen rats were used)

\begin{tabular}{|c|c|c|c|c|c|c|c|c|c|c|}
\hline \multirow{3}{*}{$\begin{array}{l}\text { Diet } \quad \ldots \\
\text { Supplement }(\mathbf{g} / \mathbf{k g})\end{array}$} & \multirow{2}{*}{\multicolumn{2}{|c|}{$\begin{array}{c}\text { Control } \\
-\end{array}$}} & \multicolumn{8}{|c|}{ Control } \\
\hline & & & \multicolumn{2}{|c|}{ L-methionine } & \multicolumn{2}{|c|}{$\begin{array}{l}\text { L-methionine } \\
\text { DL-sulphoxide }\end{array}$} & \multicolumn{2}{|c|}{$\begin{array}{l}\text { L-methionine } \\
\text { sulphone }\end{array}$} & \multicolumn{2}{|c|}{ L-cysteine } \\
\hline & Mean & SE & Mean & $S E$ & Mean & SE & Mean & SE & Mean & SE \\
\hline $\begin{array}{l}\text { Food intake }(\mathrm{g}) \\
\text { Wt gain }(\mathrm{g}) \\
\text { Plasma urea-N } \ddagger(\mathrm{mg} / \mathrm{l}) \\
\text { Urine urea-N:total } \\
\text { urine } \mathrm{N}\end{array}$ & $\begin{array}{l}45 \cdot 4 \\
17 \cdot 5 \\
50 \\
0 \cdot 496\end{array}$ & $\begin{array}{l}2 \cdot 2 \\
1 \cdot 2 \\
4 \\
0 \cdot 0019\end{array}$ & $\begin{array}{l}50 \cdot 2 \\
23 \cdot 8 \\
34 \\
0 \cdot 443\end{array}$ & $\begin{array}{l}3 \cdot 2 \\
2 \cdot 5 \\
6 \\
0 \cdot 0031\end{array}$ & $\begin{array}{l}51 \cdot 2 \\
22 \cdot 0 \\
33 \\
0 \cdot 442\end{array}$ & $\begin{array}{l}3 \cdot 2 \\
1 \cdot 4 \\
4 \\
0.0016\end{array}$ & $\begin{array}{l}40 \cdot 3 \\
18 \cdot 0 \\
66 \\
0 \cdot 632\end{array}$ & $\begin{array}{l}2.7 \\
1.8 \\
7 \\
0.0038\end{array}$ & $\begin{array}{l}47 \cdot 2 \\
19 \cdot 9 \\
18 \\
0 \cdot 364\end{array}$ & $\begin{array}{l}2 \cdot 3 \\
1 \cdot 9 \\
5 \\
0.0028\end{array}$ \\
\hline $\begin{array}{l}\text { Digestibility } \\
\text { BV } \\
\text { NPU }\end{array}$ & $\begin{array}{l}0.938 \\
0.912 \\
0.855\end{array}$ & $\begin{array}{l}0.0003 \\
0.0006 \\
0.0007\end{array}$ & $\begin{array}{l}0.933 \\
0.933 \\
0.87\end{array}$ & $\begin{array}{l}0.0011 \\
0.0007 \\
0.0016\end{array}$ & 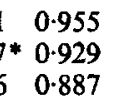 & $\begin{array}{l}0.0010 \\
0.0004^{*} \\
0.0011\end{array}$ & $\begin{array}{r}0.964 \\
0.903 \\
0.871\end{array}$ & $\begin{array}{l}0.0003 \\
0.0008 \\
0.0008\end{array}$ & $\begin{array}{l}0.925 \\
0.932 \\
0.862\end{array}$ & $\begin{array}{l}0.0007 \\
0.0004^{*} \\
0.0009\end{array}$ \\
\hline & $\begin{array}{l}* \text { Sta } \\
+\mathrm{Fo} \\
+\mathrm{Bl}\end{array}$ & ails & 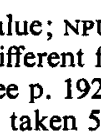 & n & . & $\begin{array}{l}\text { ilization. } \\
\text { diet }(P \text {. }\end{array}$ & . & & & \\
\hline
\end{tabular}

by supplementation with $1 \mathrm{~g} \mathrm{~L}$-methionine $/ \mathrm{kg}$ up to the same level as supplemented reference sample.

The values for plasma urea- $\mathrm{N}$ and urine urea- $\mathrm{N}$ : total $\mathrm{N}$ in urine both decreased on supplementation with L-methionine, except for the diet treated with $80 \mathrm{~g} \mathrm{H}_{2} \mathrm{O}_{2} / \mathrm{kg}$.

Since some of the S-amino acids in the fish protein were converted during the $\mathrm{H}_{2} \mathrm{O}_{2}$ treatment to oxidized derivatives (methionine sulphoxide, methionine sulphone, cysteic acid), these derivatives together with cysteine were tested for their availability in supplementation experiments. Results from supplementation of the reference sample and the sample treated with $40 \mathrm{~g} \mathrm{H}_{2} \mathrm{O}_{2} / \mathrm{kg}$ are presented in Tables 4 and 5 .

The results showed that supplementation of the reference sample and of the sample treated with $40 \mathrm{~g} \mathrm{H}_{2} \mathrm{O}_{2} / \mathrm{kg}$ with L-methionine DL-sulphoxide and cysteine, resulted in an increase of $\mathrm{BV}$ comparable to the effect of supplementation with methionine (values are compared with results from unsupplemented diets tested in parallel experiments). On the 


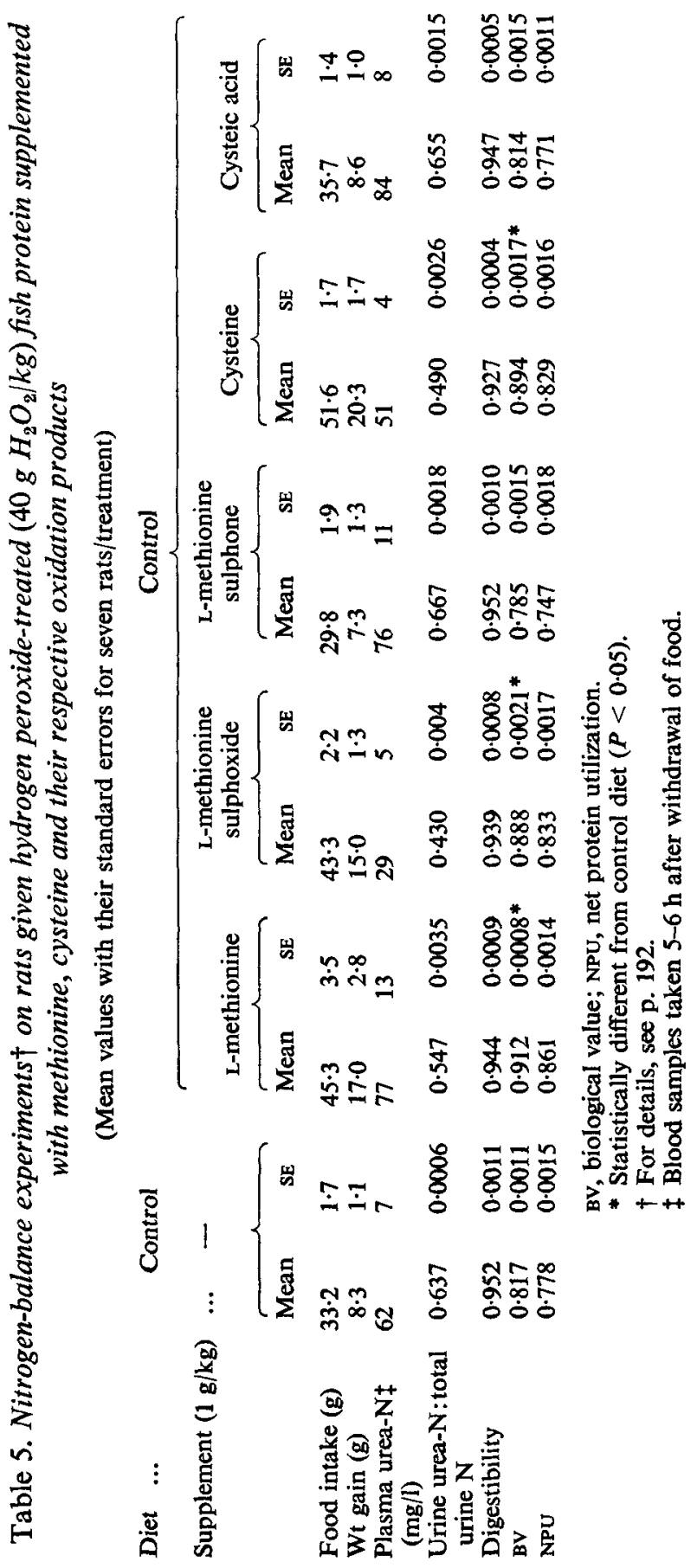


Table 6. Nitrogen-balance experiments* on rats given wheat flour supplemented with hydrogen peroxide-treated $\left(20 \mathrm{~g} \mathrm{H}_{2} \mathrm{O}_{2} / \mathrm{kg}\right)$ fish protein

(Mean values with their standard errors for seven rats/treatment)

\begin{tabular}{|c|c|c|c|c|c|c|}
\hline \multirow[t]{2}{*}{ Diet } & \multicolumn{2}{|c|}{ Wheat flour $\dagger$} & \multicolumn{2}{|c|}{$\begin{array}{l}\text { Wheat flour }+50 \mathrm{~g} \\
\text { fish protein } / \mathrm{kg}\end{array}$} & \multicolumn{2}{|c|}{$\begin{array}{l}\text { Wheat flour }+100 \mathrm{~g} \\
\text { fish protein } / \mathrm{kg}\end{array}$} \\
\hline & Mean & SE & Mean & SE & Mean & SE \\
\hline Food intake $(\mathrm{g})$ & $27 \cdot 5$ & $2 \cdot 7$ & $40 \cdot 8$ & $2 \cdot 3$ & $43 \cdot 1$ & $3 \cdot 3$ \\
\hline Wt gain $(\mathrm{g})$ & 0.8 & $0 \cdot 4$ & $13 \cdot 0$ & $1 \cdot 7$ & $19 \cdot 8$ & $2 \cdot 6$ \\
\hline Plasma urea-N $\ddagger(\mathrm{mg} / \mathrm{l})$ & 179 & 9 & 165 & 12 & 116 & 8 \\
\hline Urine urea-N: total urine & J 0.957 & 0.0029 & 0.911 & 0.0016 & 0.756 & 0.0015 \\
\hline Digestibility & 0.899 & 0.0013 & 0.872 & 0.0010 & 0.880 & $0-0011$ \\
\hline BV & 0.596 & 0.0014 & 0.709 & 0.0018 & 0.810 & 0.0022 \\
\hline NPU & 0.536 & 0.0013 & 0.622 & 0.0020 & 0.714 & 0.0016 \\
\hline & $\begin{array}{l}\text { biologic } \\
\text { or detai } \\
\text { rotein c } \\
\text { lood san }\end{array}$ & $\begin{array}{l}\text { e, NPU, } \\
\text { p. } 192 . \\
88 \mathrm{~g} / \mathrm{k} \\
\text { aken } 1\end{array}$ & protein & ation. & & \\
\hline
\end{tabular}

other hand, supplementation with L-methionine sulphone resulted in a slightly decreased food intake and BV. Supplementation with cysteic acid resulted in an unchanged BV.

A test in which combined supplements of $1 \mathrm{~g} \mathrm{~L}$-methionine $/ \mathrm{kg}$ and $1 \mathrm{~g} \mathrm{~L}$-cystine $/ \mathrm{kg}$ was added to the sample treated with $40 \mathrm{~g} \mathrm{H}_{2} \mathrm{O}_{2} / \mathrm{kg}$ resulted in a smaller increase in BV than supplementation with methionine or cystine alone.

In the 'supplementation' experiments low values for both plasma urea- $\mathrm{N}$ and urine urea-N: total $\mathbf{N}$ in urine were usually associated with high values for $\mathbf{B V}$.

As mentioned earlier, when fish protein is used as the only protein source in the diet, the BV is mainly a function of the availability of S-amino acids. To test the availability of lysine in the $\mathrm{H}_{2} \mathrm{O}_{2}$-treated fish protein, the fish protein was tested as a supplementary protein to wheat flour (see Table 6). In this diet lysine is the first limiting amino acid. Fish protein was added at 50 and $100 \mathrm{~g} / \mathrm{kg}$ wheat flour. The results showed a good supplementary effect. There was a large increase in weight gain and $\mathrm{BV}$ and there was a decrease in plasma urea- $\mathrm{N}$ and in urea- $\mathrm{N}$ : total $\mathrm{N}$ in urine. The supplementary effect was of the same magnitude as that normally found in this laboratory for fish protein not treated with $\mathrm{H}_{2} \mathrm{O}_{2}$, and showed that lysine in this sample was essentially unaffected by the treatment with $\mathrm{H}_{2} \mathrm{O}_{2}$.

\section{Studies of plasma and urine}

The concentration of free amino acids in plasma is a measurement often studied. The free amino acid concentrations in plasma from rats given a control fish-protein diet and a diet with fish protein treated with $20 \mathrm{~g} \mathrm{H}_{2} \mathrm{O}_{2} / \mathrm{kg}$ are presented in Fig. 1. The two patterns showed a great similarity which indicated that the treatment with $\mathrm{H}_{2} \mathrm{O}_{2}$ left most amino acids unaffected. However, there were two differences: in the $\mathrm{H}_{2} \mathrm{O}_{3}$-treated diet there was a new amino acid 'peak' appearing immediately before the threonine 'peak', and the height of threonine 'peak' was increased. This we thought would be explained by the fact that with the buffer system applied in this separation, one isomer of L-methionine DL-sulphoxide was eluted together with L-methionine sulphone immediately before threonine and that the other isomer of L-methionine DL-sulphoxide was eluted together with threonine. As described previously (p. 192), this complex could be further resolved by using a modified buffer system (see Fig. 2). As can be seen the two possible isomers of methionine sulphoxide were separated and methionine sulphone appeared in a separate 'peak'. Occasionally the second 


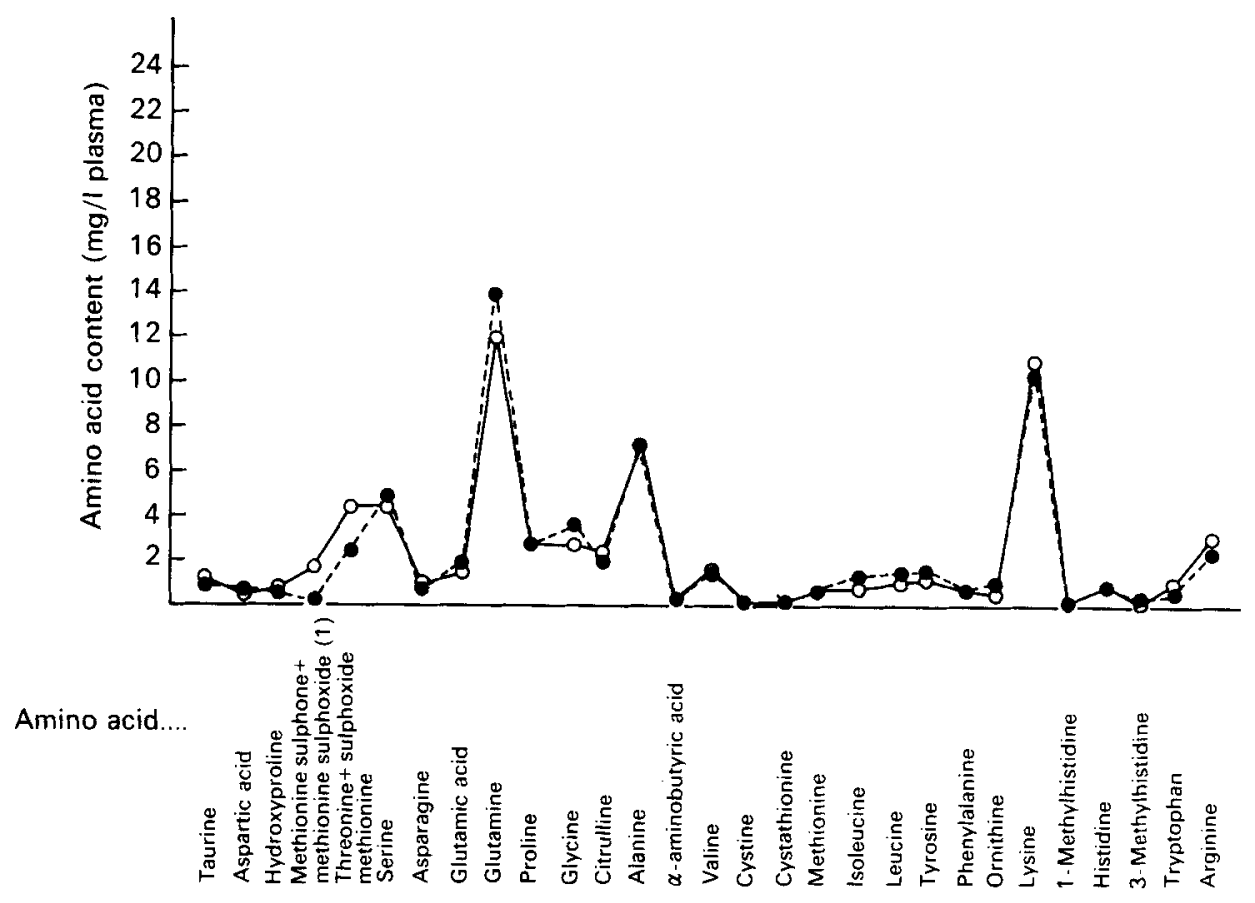

Fig. 1. Plasma 'aminogram' (obtained by ion-exchange chromatography) from rats given a diet with fish protein treated with $20 \mathrm{~g}$ hydrogen peroxide $/ \mathrm{kg}(\mathrm{O}-\mathrm{O})$ and a diet with reference fish protein (---). The points represent mean values for three determinations. For details of separation procedures, see p. 191.

'peak' for methionine sulphoxide ('peak' no. 2) was higher than the first 'peak' for methionine sulphoxide ('peak' no. 1). This was due to interference by hydroxyproline present in plasma. With a standard amino acid sample, L-methionine DL-sulphoxide gave two 'peaks' of equal size.

The results obtained indicated that the new 'peaks' on the plasma 'aminogram' were methionine sulphoxide and methionine sulphone. For further identification collection was made of corresponding plasma fractions from the ion-exchange chromatography separation. Dansyl derivatives of the amino acids were analysed by thin-layer chromatography (see p. 193). The plasma fractions contained substances with the same $R_{\mathrm{f}}$ values as standard dansyl derivatives of methionine sulphoxide and methionine sulphone.

This finding of the presence of oxidized S-amino acids in plasma prompted us to investigate the concentration of these substances in various organs and fluids. Since the work of Smith (1972) showed that the rat converted methionine sulphoxide and methionine sulphone to $\mathrm{N}$-acetylated derivatives, the possibility of the presence of acid- and alkali-labile derivatives was also investigated. The results are presented in Table 7. The results showed that in plasma methionine sulphoxide was present in higher concentrations than methionine sulphone. The value for methionine sulphoxide was approximately twice that normally found for methionine in plasma. Values for cysteic acid in plasma were probably affected by interference from other substances, because values obtained with a $\mathrm{H}_{2} \mathrm{O}_{2}$-treated fish-protein diet were of the same magnitude as values obtained with a reference fish-protein diet. However, the corresponding 'peak' obtained on chromatography of plasma appeared at the position for cysteic acid, and showed no asymmetry. This was true for other tissues also. Values for methionine sulphoxide in plasma were dependent on the protein concentration 


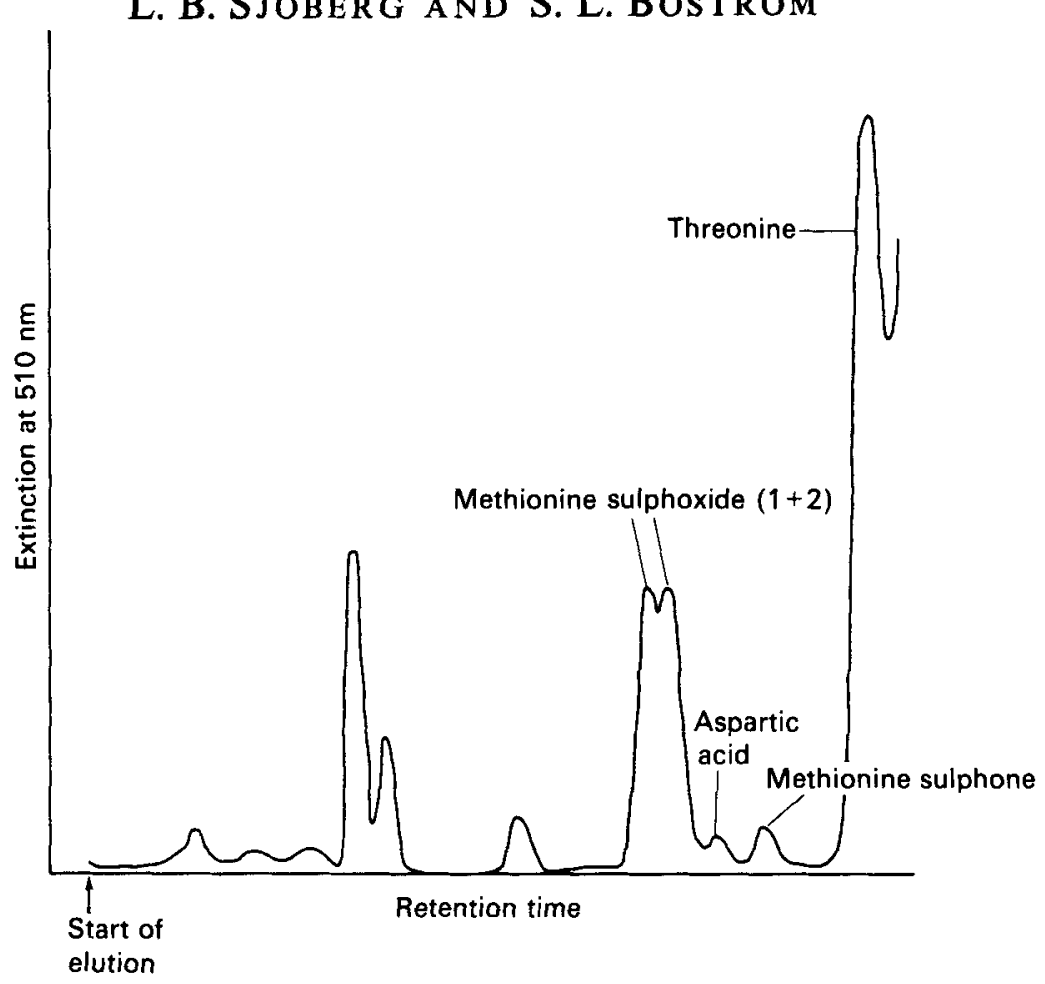

Fig. 2. A portion of a representative recorder trace obtained on ion-exchange chromatography of plasma from a rat given a diet with fish protein treated with $40 \mathrm{~g}$ hydrogen peroxide $/ \mathrm{kg}$. This indicates the pattern of elution of the oxidized sulphur-amino acids from the ion-exchange resin. For details of separation procedures, see p. 191.

in the diet. Studies with $250 \mathrm{~g}$ protein $/ \mathrm{kg}$ in the diet gave, after $5 \mathrm{~d}$ on the diet, the following concentrations (mean $\pm \mathrm{SE} ; \mathrm{mg} / \mathrm{ml}$ plasma): methionine sulphoxide $16 \cdot 7 \pm 1 \cdot 1$, methionine sulphone $0.49 \pm 0.02$.

In urine only traces of methionine sulphoxide were found, but there were large amounts of methionine sulphone which were almost all present as an acid-labile derivative. Results from kidney, liver and muscle are at present few and uncertain due to substances interfering during chromatography of samples. This was particularly true for methionine sulphoxide and cysteic acid. The results, however, indicated the presence of methionine sulphoxide and methionine sulphone in all these organs and there was no evidence of the presence of an acid-labile derivative of methionine sulphone or alkali-labile derivatives of methionine sulphoxide. The concentration of cysteic acid seemed to be particularly high in the kidney. No evidence was found for the presence of acid-labile derivatives of cysteic acid.

The elimination rate of methionine sulphoxide and methionine sulphone from plasma was studied in an experiment where rats were maintained for $8 \mathrm{~d}$ on a diet with fish protein treated with $40 \mathrm{~g} \mathrm{H}_{2} \mathrm{O}_{2} / \mathrm{kg}$, followed by $8 \mathrm{~d}$ recovery on a diet with reference fish protein. Concentrations of methionine sulphoxide and methionine sulphone in plasma and urine were followed during the recovery period. The results showed that in plasma the levels of methionine sulphoxide and methionine sulphone decreased to trace amounts after only $1 \mathrm{~d}$ on the reference-protein diet. In urine (Table 7) only trace quantities of free methionine sulphoxide could be found. However, methionine sulphone (determined after acid-hydrolysis, which gave a value for free methionine sulphone + acid-labile derivatives of methionine sulphone) was excreted in urine during almost the whole recovery period and showed a 
Table 7. The content of oxidized sulphur-amino acids in plasma, urine, kidney, liver and muscle from rats given $\left(40 \mathrm{~g} \mathrm{H}_{2} \mathrm{O}_{2} / \mathrm{kg}\right)$-treated fish protein

(Mean values with their standard errors; no. of rats in parentheses)

Tissue content

\begin{tabular}{|c|c|c|c|c|c|c|c|}
\hline \multirow[b]{2}{*}{ Tissue } & \multirow{2}{*}{$\begin{array}{c}\text { Oxidized } \\
\text { S-amino acid }\end{array}$} & \multicolumn{2}{|c|}{$\begin{array}{l}\text { As the free } \\
\text { compound* }\end{array}$} & \multicolumn{2}{|c|}{$\begin{array}{l}\text { After acid- } \\
\text { hydrolysis* }\end{array}$} & \multicolumn{2}{|c|}{$\begin{array}{l}\text { After alkaline- } \\
\text { hydrolysis* }\end{array}$} \\
\hline & & Mean & SE & Mean & SE & Mean & SE \\
\hline Plasma (mg/l) & $\begin{array}{l}\text { Methionine sulphoxide } \\
\text { Methionine sulphone } \\
\text { Cysteic acid }\end{array}$ & $\begin{array}{l}9 \cdot 2 \\
3 \cdot 4 \\
2 \cdot 8\end{array}$ & $\begin{array}{l}1.4(4) \\
0.4(4) \\
0.2(4)\end{array}$ & $\begin{array}{l}3 \cdot 7 \\
7.9\end{array}$ & $\begin{array}{l}\text { nd } \\
0.2(4) \\
1.4(3)\end{array}$ & $\begin{array}{l}9.0 \\
4 \cdot 5\end{array}$ & $\begin{array}{l}0.4(4) \\
0.5(4) \\
\text { nd }\end{array}$ \\
\hline Urine (mg/l) & $\begin{array}{l}\text { Methionine sulphoxide } \\
\text { Methionine sulphone } \\
\text { Cysteic acid }\end{array}$ & $\begin{array}{l}1 \cdot 7 \\
1 \cdot 0 \\
6 \cdot 4\end{array}$ & $\begin{array}{l}0.4(4) \\
0.4(4) \\
5.0(4)\end{array}$ & $\begin{array}{r}58 \cdot 1 \\
7 \cdot 8\end{array}$ & $\begin{array}{l}\text { nd } \\
9 \cdot 6(4) \\
2 \cdot 6(4)\end{array}$ & & $\stackrel{+}{\dagger}$ \\
\hline Kidney (mg/g) & $\begin{array}{l}\text { Methionine sulphoxide } \\
\text { Methionine sulphone } \\
\text { Cysteic acid }\end{array}$ & $\begin{array}{l}3 \cdot 30 \\
4 \cdot 93 \\
4 \cdot 44\end{array}$ & $\begin{array}{l}0.10(2) \\
1.42(3) \\
0.55(3)\end{array}$ & $\begin{array}{l}4 \cdot 19 \\
4 \cdot 48\end{array}$ & $\begin{array}{l}\text { nd } \\
0.98(3) \\
0.92(3)\end{array}$ & 3.98 & $\begin{array}{l}\dagger \\
\text { nd } \\
0.84(3)\end{array}$ \\
\hline Liver (mg/g) & $\begin{array}{l}\text { Methionine sulphoxide } \\
\text { Methionine sulphone } \\
\text { Cysteic acid }\end{array}$ & $\begin{array}{l}1.69 \\
0.49\end{array}$ & $\begin{array}{l}\dagger \\
0.25(4) \\
0.06(4)\end{array}$ & $2 \cdot 22$ & $\begin{array}{l}\text { nd } \\
+ \\
\dagger\end{array}$ & $1 \cdot 10$ & $\stackrel{\dagger}{0.14(4)}_{\text {nd }}^{+}$ \\
\hline Muscle (mg/g) & $\begin{array}{l}\text { Methionine sulphoxide } \\
\text { Methionine sulphone } \\
\text { Cysteic acid }\end{array}$ & $\begin{array}{l}2 \cdot 40^{5} \\
0.73\end{array}$ & $\begin{array}{l}10+(4) \\
0 \cdot 40(4) \\
0 \cdot 14(4)\end{array}$ & $2 \cdot 58$ & $\begin{array}{l}\text { nd } \\
\uparrow \\
\dagger\end{array}$ & $\begin{array}{l}8 \cdot 19 \\
2 \cdot 74\end{array}$ & $\begin{array}{r}0.10(2) \\
0.56(2) \\
\text { nd }\end{array}$ \\
\hline
\end{tabular}

Table 8. Distribution in urine and faeces of orally-ingested oxidized sulphur-amino acids from hydrogen peroxide-treated fish protein*

(Mean values with their standard errors for seven rats/treatment)

$\begin{array}{lccccc}\begin{array}{l}\text { Oxidized S-amino } \\ \text { acid ... }\end{array} & \text { Methionine } & \begin{array}{c}\text { Methionine } \\ \text { sulphoxide }\end{array} & \begin{array}{c}\text { Methionine } \\ \text { sulphone }\end{array} & \text { Cysteic acid } & \text { Cystine } \\ \text { Consumed (mg) } & 31 \cdot 9 \pm 1.9 & 85 \cdot 1 \pm 5 \cdot 13 \dagger & 5 \cdot 60 \pm 0.33 \ddagger & 27 \cdot 0 \pm 1 \cdot 63 \ddagger & 24.9 \pm 1.5 \\ \text { Excreted in faeces (mg) } & 2 \cdot 80 \pm 0.31 & 2 \cdot 15 \pm 0.24 \dagger & 0.46 \pm 0.08 \ddagger & 1 \cdot 21 \pm 0.15 \ddagger & 5 \cdot 08 \pm 0.45 \\ \text { Excreted in urine (mg) } & \text { nd } & \text { trace } \| & 2.68 \pm 0.39 \| & 0.47 \pm 0.03 \S & \text { nd }\end{array}$

nd, not determined.

* This batch of $\mathrm{H}_{2} \mathrm{O}_{2}$-treated fish protein had the following content of S-amino acids (mg/g protein (nitrogen $\times 6.25$ ) ): methionine 0.91 , methionine sulphoxide 2.43 , methionine sulphone $0 \cdot 16$, cystine 0.71 , cysteic acid 0.77 .

$\dagger$ Determined by 'indirect' method (see p. 192).

† Determined after acid-hydrolysis (see p. 191).

$\S$ Determined by ion-exchange chromatography after acid-hydrolysis (see p. 193).

II Determined by ion-exchange chromatography after protein precipitation with acetone followed by acid-hydrolysis (see p. 193). Value includes free methionine sulphone as well as acid-labile derivatives of methionine sulphone.

progressive decrease in concentration from approximately $50 \mathrm{mg} / \mathrm{l}$ urine the day before the change in diet, to approximately $1 \mathrm{mg} / \mathrm{l}$ urine after the $8 \mathrm{~d}$ recovery period.

To obtain an over-all pattern of the utilization of S-amino acids in $\mathrm{H}_{2} \mathrm{O}_{2}$-treated fish protein, an experiment was designed in which, during a $4 \mathrm{~d}$ period, intake and excretion in faeces and urine of S-amino acids were determined. The results are presented in Table 8. The results showed that rats absorbed more than $90 \%$ of the peptide-bound oxidized 
S-amino acids. For methionine sulphone, about $50 \%$ of that absorbed was excreted in urine. Results in Table 7 showed that most of this was excreted as acid-labile derivatives. Only about $55 \%$ of the methionine sulphone consumed could be recovered in urine and faeces. For methionine sulphoxide, only trace quantities of free substance were found in urine. A value for acid-labile derivatives of methionine sulphoxide in urine could not be determined because of the instability of methionine sulphoxide during mild acid-treatment, but the small increase of methionine after acid-hydrolysis indicated that only small amounts of methionine sulphoxide derivatives were excreted in urine.

As previously mentioned, values for cysteic acid in urine were subject to some uncertainty due to interference from unknown substances. Only approximately $6 \%$ of the cysteic acid consumed could be recovered as free cysteic acid + acid-labile derivatives in urine and faeces.

\section{DISCUSSION \\ Chemical evaluation}

$\mathrm{H}_{2} \mathrm{O}_{2}$ is a relatively non-specific oxidizing agent and therefore several amino acids in a protein treated with $\mathrm{H}_{2} \mathrm{O}_{2}$ would be expected to be modified. Our results showed that treatment of fish protein with $\mathrm{H}_{2} \mathrm{O}_{2}$ under alkaline conditions had oxidized mainly the S-amino acids, but at higher concentrations of $\mathrm{H}_{2} \mathrm{O}_{2}$, tryptophan and lysine were also oxidized.

According to Neumann (1967), cystine and cysteine would be more sensitive to oxidation than methionine under alkaline conditions. At acid $\mathrm{pH}$ the reverse would be true. Our results in comparison with the results of Slump \& Schreuder (1973) seem to verify this. Slump \& Schreuder (1973) oxidized fish meal at acid pH and got an almost total conversion of methionine into methionine sulphoxide but only about $25 \%$ of the cystine-cysteine was oxidized. In our study, treatment with $20 \mathrm{~g} \mathrm{H}_{2} \mathrm{O}_{2} / \mathrm{kg}$ at alkaline $\mathrm{pH}$ resulted in approximately $65 \%$ oxidation of the methionine and approximately $55 \%$ oxidation of the cystine. Since all methionine and cystine could be recovered, there seems to be no actual destruction of S-amino acids. Rasekh et al. (1972) treated fish-protein concentrate with $\mathrm{H}_{2} \mathrm{O}_{2}$ at a neutral $\mathrm{pH}$. Although they did not determine the amounts of oxidized S-amino acids, they found that treatment with $50 \mathrm{~g} \mathrm{H}_{2} \mathrm{O}_{2} / \mathrm{kg}$ fish-protein concentrate resulted in only very small reductions in the contents of tryptophan, tyrosine and histidine. Our results (L. B. Sjöberg \& S. L. Boström, unpublished results) from treatment of fish protein with $\mathrm{H}_{2} \mathrm{O}_{2}$ at a $\mathrm{pH}$ between 7.5 and 8 are in accordance with those of Rasekh et al. (1972). This indicates that treatment with $\mathrm{H}_{2} \mathrm{O}_{2}$ at alkaline $\mathrm{pH}$ causes a higher extent of amino acid modification than treatment at neutral $\mathrm{pH}$. In this study, alkaline $\mathrm{pH}$ was selected since previous experiments had shown that this condition gave maximum bleaching effect and optimum functional properties of the fish protein.

One detail of interest is the presence of methionine sulphoxide in the reference fish protein. Slump \& Schreuder (1973) also found methionine sulphoxide in fish protein which had not been treated with $\mathrm{H}_{2} \mathrm{O}_{2}$. Kido \& Kassell (1975) reported the presence of methionine sulphoxide in native porcine pepsin and in pepsin exposed to $\mathrm{pH} 3.2$ at $30^{\circ}$ for $70 \mathrm{~min}$. These findings indicate that some methionine residues in various types of protein are very easily oxidized to methionine sulphoxide during handling of the protein material.

\section{Biological evaluation}

Treatment of fish protein did not affect the over-all digestibility of the protein. These results are in accordance with the results of Slump \& Schreuder (1973). Specific analysis of S-amino acids in faeces (Table 8) also showed that the uptake of S-amino acids was high. Consequently, the results from in vivo studies do not parallel the results of Cuq et al. (1973), 
which showed a decreased digestibility of methionine sulphoxide peptide bonds during in vitro digestion with Pronase.

The results from $\mathrm{N}$-balance experiments and growth experiments show that treatment with $\mathrm{H}_{2} \mathrm{O}_{2}$ gives a small decrease in nutritional value. These results together with results showing low levels of methionine sulphoxide in the faeces indicates that peptide-bound methionine sulphoxide is available to rats and that the reduced $\mathrm{BV}$ is at least partly due to the formation of methionine sulphone and cysteic acid. This conclusion is in accordance with the conclusion of Slump \& Schreuder (1973). The results also show that the decrease in BV can almost equally well be compensated by addition of $1 \mathrm{~g} \mathrm{~L}$-methionine $/ \mathrm{kg}, 1 \mathrm{~g}$ $\mathrm{L}$-cystine $/ \mathrm{kg}$ or $1 \mathrm{~g}$ L-methionine DL-sulphoxide $/ \mathrm{kg}$, but not by methionine sulphone or cysteic acid. That free L-methionine DL-sulphoxide can be utilized by the rat has previously been shown by Njaa (1962), Miller \& Samuel (1968) and Miller et al.(1970). That methionine sulphone and cysteic acid could not be used as a supplement to a casein diet was shown by Miller \& Samuel (1968).

It has been shown that the relative amount of each S-amino acid as well as the total quantity of S-amino acids affects the growth of rats (Byington, Hoove \& Clark, 1972). That cystine could partly replace methionine when the methionine level was suboptimal was shown by Womack \& Rose (1941). The results presented in this study show that cystine also has a 'methionine-sparing' effect when the organic $S$ is supplied mainly in the form of methionine sulphoxide.

If the decrease in $\mathrm{BV}$ is due to the formation of methionine sulphone and cysteic acid, one would expect to find a parallel decrease in BV as the concentration of methionine sulphone and cysteic acid increase. This was observed by Slump \& Schreuder (1973) but was not found in our investigation, and we have no explanation for this. In the PER studies, we obtained a stepwise reduction in PER values with increasing concentration of $\mathrm{H}_{2} \mathrm{O}_{2}$. Rasekh et al. (1972) did not find any significant difference in PER values for fish protein treated with $12 \cdot 5-50 \mathrm{~g} \mathrm{H}_{2} \mathrm{O}_{2} / \mathrm{kg}$.

Urea concentration in plasma was found to be a most valuable indicator of protein quality, even though the animals were fed ad lib, which meant different absolute protein intakes on different diets. Also the ratio, urine urea- $N$ : total $N$ in urine is a good indicator of protein quality.

\section{Studies on the metabolism of oxidized S-amino acids}

The presence of free methionine sulphoxide and methionine sulphone in plasma, liver, kidney, muscle and urine was established by ion-exchange chromatography after protein precipitation with sulphosalicylic acid. Methionine sulphoxide appeared as two 'peaks' on the chromatogram obtained with plasma which would be expected since oxidation of peptide-bound L-methionine gives L-methionine DL-sulphoxide. Usually, but not always, the two 'peaks' were of equal height. This indicated that the rate of disappearance from plasma of the two isomers was similar.

Miller et al. (1970) reported the presence of large amounts of a 'methionine' compound in plasma from rats given a diet containing free methionine sulphoxide. They could not identify the substance but concluded that it was not methionine, methionine sulphoxide, methionine sulphone or homocystine. Anderson et al. (1975) reported the presence of both methionine sulphoxide and methionine sulphone in plasma from rats given $\mathrm{H}_{2} \mathrm{O}_{2}$-treated rapeseed flour. Since our interpretation of our plasma 'aminograms' also indicated the presence of methionine sulphoxide, efforts were made to get further evidence of its presence. As reported this was done by thin-layer chromatography of dansyl derivatives. Efforts to get further evidence by mass spectrometry failed due to the instability of methionine sulphoxide. 
Smith (1972) showed that the rat converts methionine sulphoxide into $\mathrm{N}$-acetyl-methionine sulphoxide, and he speculated that this might be the substance observed by Miller et al. (1970) in plasma. To check that the methionine sulphoxide we found in plasma was not the result of breakdown of acetylated methionine sulphoxide during protein precipitation with strong acid, the following experiment was done. Samples of plasma were deproteinized with acetone followed either by direct ion-exchange chromatography or alkaline-hydrolysis followed by ion-exchange chromatography. The two treatments gave similar results, which further indicated that the methionine sulphoxide in plasma was at least mainly in the free form and that there was very little or no alkali-labile derivative like $\mathrm{N}$-acetyl-methionine sulphoxide.

In the work of Miller et al. (1970) exceptionally high concentrations of free methionine sulphoxide (isomer unspecified) were added to the diet $(62.5 \mathrm{mg} \mathrm{L}$-methionine sulphoxide $/ \mathrm{g}$ amino acid mixture; $180 \mathrm{~g}$ amino acid mixture $/ \mathrm{kg}$ diet). In our supplementation experiment, in which $1 \mathrm{~g}$ free $\mathrm{L}$-methionine DL-sulphoxide $/ \mathrm{kg}$ was added, we also determined the plasma concentration of methionine sulphoxide. A reference fish protein supplemented with $1 \mathrm{~g} \mathrm{~L}$ methionine DL-sulphoxide/ $\mathrm{kg}$ gave a plasma concentration of $6.7 \pm 1.2 \mathrm{mg} / \mathrm{l}$ plasma. Supplementation with $5 \mathrm{~g}$ L-methionine DL-sulphoxide/kg gave a concentration of $123.3 \pm$ $18 \mathrm{mg} / 1$ plasma. This indicated that also on a diet supplemented with free methionine sulphoxide, free methionine sulphoxide appears in plasma.

Miller et al. (1970) observed a time-dependent decrease in the 'methionine' level in plasma and explained this by an adaptation of the rat. In our work on $\mathrm{H}_{2} \mathrm{O}_{2}$-treated fish protein we did not observe any differences in plasma methionine sulphoxide level after $10 \mathrm{~d}$ or $28 \mathrm{~d}$ on the diet.

Apart from plasma the presence of methionine sulphoxide, methionine sulphone and cysteic acid was indicated in liver, kidney, muscle and urine. In urine almost all the methionine sulphone was excreted as an acid-labile derivative which, based on the results of Smith (1972) and Wingo, Smith \& Wood (1953) could be the $N$-acetyl derivative or a conjugate with glutamic acid. It would be expected that the conjugation takes place in the kidney, but since acid-labile derivatives were not found in the kidney, our suggestion is that the conjugation takes place in connexion with the excretion of the molecule.

The over-all distribution in urine and faeces of ingested oxidized S-amino acids showed that only less than $3 \%$ of the ingested methionine sulphoxide could be recovered. This is a further indication that protein-bound methionine sulphoxide is utilized by the rat. On the other hand approximately $55 \%$ of the ingested methionine sulphone was recovered in urine and faeces. For cysteic acid the recovery was only $6 \%$ which indicates that cysteic acid is metabolized.

The authors thank Mrs I. Califf and A. Enhbåge for technical assistance and Miss A. Ahlenius and $\mathrm{Mr}$ B. Evenmyr for their care of experimental animals. This investigation was supported by grant 74-6582a $+b$ from the Swedish Board of Technical Development.

\section{REFERENCES}

Anderson, G. H., Li, G. S. K., Jones, J. D. \& Bender, F. (1975). J. Nutr. 105, 317.

Association of Official Analytical Chemists (1970). Official Methods of Analysis. Washington, DC: Association of Official Analytical Chemists.

Byington, M. H., Hoove, J. M. \& Clark, H. E. (1972). J. Nutr. 102, 219.

Cuq, J. L., Provansal, M., Guilleux, F. \& Cheftel, C. (1973). J. Fd Sci. 38, 11.

Eggum, B. (1973). In Protein in Human Nutrition, p. 317. [J. W. G. Porter and B. A. Rolls, editors.] London and New York: Academic Press.

Ellinger, G. M. \& Palmer, R. (1969). Proc. Nutr. Soc. 28, 42 A.

Gray, W. R. \& Hartley, B. S. (1963). Biochem. J. 89, 59. 
Gros, C. \& Labousse, B. (1969). Eur. J. Biochem. 7, 463.

Hills, G. L. \& Thiel, G. C. (1945). J. Dairy Res. 14, 340.

Ivanetich, K. M., Bradstrom, J. J. \& Kaminsky, L. S. (1976). Biochemistry, Easton 15, 1144.

Jeppsson, J. O. \& Karlsson, I. M. (1972). J. Chromatog. 72, 93.

Kido, K. \& Kassell, B. (1975). Biochemistry, Easton 14, 631.

Miller, D. S. \& Samuel, P. (1968). Proc. Nutr. Soc. 27, 21 A.

Miller, S. A., Tannenbaum, S. R. \& Seitz, A. W. (1970). J. Nutr. 100, 909.

Moore, S. (1963). J. biol. Chem. 238, 235.

Neumann, N. P. (1967). Meth. Enzym. 11, 485.

Njaa, L. R. (1962). Br. J. Nutr. 16, 571 .

Perry, T. L. \& Hansen, S. (1969). Clinica chim. Acta 25, 53.

Rasekh, J., Stillings, B. R. \& Sidwell, R. (1972). J. Fd Sci. 37, 423.

Slump, P. \& Schreuder, H. A. W. (1973). J. Sci. Fd Agric. 24, 657.

Smith, R. C. (1972). Biochim. Biophys. Acta 261, 304.

Spies, J. R. \& Chambers, D. C. (1948). Analyt. Chem. 20, 30.

Spies, J. R. \& Chambers, D. C. (1949). Analyt. Chem. 21, 1249.

Stein, W. H. \& Moore, S. (1954). J. biol. Chem. 211, 915.

Stillings, B. R., Hammerle, O. H. \& Snyder, D. G. (1969). J. Nutr. 97, 70.

US Pharmacopoeia, XIV (1950). p. 789.

Wingo, W. J., Smith, R. A. \& Wood, J. (1953). Archs Biochem. Biophys. 47, 307.

Womack, M. \& Rose, W. C. (1941). J. biol. Chem. 141, 375. 